\title{
North Korea’s Middle School Education
}

\author{
Shin, Ju-Cheol \\ (Korean Education, HUFS) \\ Seoul, Korea \\ maybe0@hufs.ac.kr
}

\begin{abstract}
This article was written through interview with defectors who escaped to South Korea after finishing middle school course in the North, in order to know the reality of North Korean education. North Korea's fundamental principle of guidance is to foster communistic. The ultimate goal of the regime's education is to make all the students communistic revolutionary warriors who are loyal to Kim Il-sung's family.
\end{abstract}

Keywords - North Korea; education; middle school; interview

\section{INTRODUCTION}

It has been over 20 years after the Soviet Union's iron curtain had collapsed- however, North Korea maintains its own curtain and remains isolated from the rest of the world. For the very reason, it is very difficult for an individual researcher, not a country's intelligence agency, to obtain information on North Korea. The North's situation can be assumed only through information released by its state-run media, such as 〈Rodong Sinmun〉 ("Newspaper of the workers") and $<$ Korean Central News Agency>. The isolation of North Korea is a big obstacle when individual researchers study on North Korean studies.

With the same limitation applying to the North Korean education field, especially the education at the chalkface is almost unknown. There are two ways- official and unofficialto grasp their actual education. The official way is to study the educational system, the educational administration, and the textbooks because a country's real education finds a shape with them. South Korea has been interested in North Korea's education since the mid-1970s; Park Won Gyu’s ‘An Analysis on North Korea's Current Education Policy and Scientific Technology'(1976) ${ }^{1}$ is the first thesis on the North's education. South Korea has conducted researches into the North Korean education in two ways - one is studying on the education policy and administration; the other on the textbooks. The former was intensively conducted from the mid-1970s to 1990s, the latter, started in the mid-1980s, is still in progress.

To overcome the limitation of the text-centered research, this article will actively utilize a means - interview with defectors who live in South Korea - besides the official one. As mentioned above, studies on the North Korean Education mainly done by analyzing its policies and textbooks, cannot reach the concealed reality because of its isolation. In this situation, it is very useful to interview defectors who escaped to South Korea after finishing middle school course in the North,

\footnotetext{
${ }^{1}$ Park Won Gyu. 'An Analysis on North Korea’s Current Education Policy and Scientific Technology'. master's degree thesis at Graduate School of Kyunghee University, 1976.
}

in order to know the reality that cannot be accessed through the official way. ${ }^{2}$ To understand the current situation of North Korean education, the author interviewed 38 students, undergraduates and postgraduates of South Korean universities who escaped from the North. ${ }^{3}$ Since defectors who have not been more than three years in the South are under South Korea's intelligence agency's protection, the interviewees were the ones who had been in the South more than five years after their settlement and lived a relatively free life. ${ }^{4}$

The main purpose of this paper is to analyze the unknown reality of the North Korean educational system and the North Korea's middle school education through the interviews with the defectors. This study will be able to contribute to the understanding of the trends in the North's education at the chalkface.

\section{GENERAL EDUCATIONAL PURPOSES}

North Korea's educational policies basically comply with the decision of the Party Congress of the Worker's Party, but the backbone of the policies is based on Kim Il-sung ${ }^{5}$ 's teachings. This is verified in the North's discourse on education when representing the necessity of certain educational policies or education, the appropriateness of the direction of the policies is argued by repeatedly quoting Kim Il-sung's teachings, such

\footnotetext{
${ }^{2}$ The authors do not put $100 \%$ trust in the interviews. The informatio $\mathrm{n}$ can be glamorized or distorted by the interviewees' personal and pol itical interests and the circumstances they were under. Nevertheless, it is judged that the information they provide is meaningful in aspect of detailed real life.

${ }^{3}$ The authors have given a lecture on 'Understanding of North Korea n Culture and Education' every semester since 2009, in which student $\mathrm{s}$ from North Korea take up around $60 \%$ of those who take the class. An assignment to analyze South and North Koreas' textbooks is given to the students to help them understand better the ways of the two co untries' teaching process. The authors, through personal and group int erviews as well as surveys with the defectors, grasp how teaching is $p$ erformed in each region and each school system.

${ }^{4}$ This article will mainly utilize the interviews with the students who allowed their real names to be exposed, and assumed names or letters such as A, B will be used for those who didn't.

${ }^{5} \mathrm{Kim}$ Il-sung is the first leader of North Korea, who governed the stat e with the Juche ideology and died in 1994.
} 
as 'Theses on Socialist Education'(1977.09.05), ${ }^{6}$ or Kim Jong-I 7's, 'On Further Developing Educational Work'(1984.07.22).

Kim Il-sung gave a speech about the 'Theses on Socialist Education' (1977.09.05) in the 14th round of the general assembly of the $5^{\text {th }}$ Workers Party Central Committee. According to the speech, the basic principle of socialist education is to make North Koreans revolutionized, workingclass, and communized, and its purpose is to foster communistic revolutionary talented people, who have initiative and creativeness. ${ }^{9}$ In other words, the basic plan of North Korea's socialistic education is ideologically converting people while elaborating their cultural level, to cultivate 'new communistic human beings' in the end. To achieve this goal, the North has put forward five methods: first, education for enlightenment; second, combination of theory and practice; third, combination of education and productive labor; fourth, reinforcement of organizational life and socio-political activities; fifth, promotion of preschool education, school education and adult education. ${ }^{10}$

North Korea's articles no.45 and no.47 of the Socialist Constitution oblige to give free education for 11 years, to accomplish the educational goal, cultivating 'communistic new human beings'. This compulsory education for the six to seventeen year olds consists of: kindergarten for one year; primary school for four years; middle school for six years. ${ }^{11}$ The current free education includes waiving tuition, providing textbooks, and giving school uniforms every two-three years. According to the defectors, meals are only given in kindergartens, and since primary and middle schools don't provide meals, students bring lunch or eat home.

There have been slight modifications in North Korea's middle school curriculum in 1968, 1983, 1986, 1992 and 1996. Due to a serious disaster from 1994 to 1997, the North went into the 'North Korean Famine (Arduous March)' period - so, the main interest of its regime during this period was to overcome the food shortage. Since the disaster seriously damaged its industry, its industrial productivity was sharply decreased, which made a huge problem with building up 'Strong and Prosperous Nation' that North Korea had been advocating. Afterwards, to maintain its unstable government, it advocated the 'Songun (Military First)' policy and strengthened its ideology propaganda and instigation. It means that the North could not school textbooks after 1996 - as the Arduous March finished in 2002, the state started revising them

${ }^{6}$ Kim Il-sung. ‘Theses on Socialist Education'. Kim Il-sung Chojakji p(Collection of Works by Kim Il-sung) 32. Pyongyang: Joseon Rodon gdang Publisher, 1986. pp.372-418.

${ }^{7}$ Kim Jong-il is the second leader of North Korea, who inherited the government power from his father, Kim Il-sung, and governed the sta te with the Songun Ideology until his death for a heart attack. Before his death, he handed over the regime to his third son, Kim Jong-un.

${ }^{8}$ Kim Jong-il. 'On Further Developing Educational Work'. Kim Jong -il Chojaksonjip(Selected Works of Kim Jong-il) 8. Pyongyang: Joseo n Rodongdang Publisher, 2006. pp.101-130.

${ }^{9}$ Kim Il-sung. ibid., p.374.

${ }^{10}$ Kim Il-sung. ibid., pp.390-399.

${ }^{11}$ The articles no. 45 and no. 47 of the Socialist Constitution are also b ased on the content of 'Theses on Socialist Education'. Kim Il-sung. i bid., p.404. again. It is assumed that there would have been some changes in curriculum at the time, but it is impossible to ascertain the whole facts since only some of the textbooks were imported in South Korea. It is highly likely that current North Korea under Kim Jong-un's regime started the education with his revolutionary history included in the curriculum.

\section{THE LIFE OF MIDDLE SCHOOL STUDENTS}

The regular class in middle school begins at 8 o'clock in the morning, but students have to come before 7 o'clock and clean up, for example, the classrooms, hallways, and playgrounds for 30 minutes. Before class starts, for 10 minutes, teachers tell students what President Kim Il-sung did on the same date of the same month. For example, if today were the 13th of November 2010, the teacher would inform the students of Kim Il-sung's teaching or instruction in the field on the $13^{\text {th }}$ of November. According to the defectors from North Korea, it is the most important daily work that must be done.12 Those who went to middle school after 1996 testified that they were informed of not only Kim Il-sung's achievement but also, from time to time, current issues and affairs. ${ }^{13}$

The students have 45-minute class and 10-minute break. Their lunchtime is from 12:30pm to $1: 30 \mathrm{pm}$, during which they have lunch they brought or eat home. All the classes of middle school end at 2:30pm. About after-school activities, the testimonies given by those who graduated from middle school before 1996 and after the year are different. A defector ${ }^{14}$ who graduated in 1996 said that after-school activities were performed at a student's home or construction site. When the students are mobilized for labor, they usually help carrying subsidiary materials or run small errands at the place; when they are not, 30 students in a class make groups of six, and each group go to one of the group member's home for class review and preparation for the next class. They go home after doing this around 5-6 o'clock.

However, defectors who graduated after 1996 said that there were no certain after-school activities, so they could hang around or study with classmates in the school when they were not mobilized for construction sites. ${ }^{15}$ Except in farming seasons, all the $4^{\text {th }}$ to $6^{\text {th }}$ graders are mobilized to give support to the farming areas for 30 to 40 days without class. ${ }^{16}$ Putting together the testimonies of the graduates before 1996 and after, the mobilization was only for farm village, so it seems that they were not sent to construction sites after 1996.

${ }^{12}$ Dong Myong-suk: 36-year-old, female, escaped from North Korea i n 1998, graduated from middle school in the North in 1996, ABD in $t$ he South from University of North Korean Studies(date of interview: 3:00pm 5:00pm on March $3^{\text {rd }}$, 2012).

${ }^{13}$ Choi Hyon-hwa: 24-year-old, male, from Cheongjin, North Hamgy ong Province, escaped from North Korea in 2008, graduated from mi ddle school in the North(date of interview: 11:30am 3:00pm, April $4^{t}$ $\mathrm{h}, 2012)$

${ }^{14}$ Dong Myong-suk: person above.

${ }^{15}$ Kim Jin-myong: 32-year-old, female, from Saetbyol, North Hamgy ong Province, escaped from North Korea in 1998. Date of interview: 11:30am 3:00pm on April $4^{\text {th }}$, 2012)

${ }^{16}$ On the contrary, Dong Myong-suk testifies that all the students are mobilized. 
The group activity corresponds to the fourth article of Kim Il-sung's teachings on education, examples of collective life, based on strengthening organizational life and socio-political activity. Mobilizing students for construction sites or farming areas is related to the third article, which argues the combination of education and productive labor. However, it can also be said that students are mobilized for labor on purpose to make up for the lack of it.

The most distinguishing characteristic of the North's education is that students have the same homeroom teacher throughout their whole middle school years until graduation, except under unavoidable circumstances, since it is a ground rule for the teachers to help their students through the graduation. It is said that as a homeroom teacher gets promoted with students from the first grade, he/she knows well about the students' personalities, attitudes, family circumstances, and grades - so it is easier for him/her to guide and interact with them. In some cases, when a teacher is transferred to another school, some students also get transferred following their teacher. It is also said that students can change their class if there is a problem between them and their teacher, without any disadvantage.

In North Korea, teachers' qualifications and abilities are of importance, as emphasized in Kyowon Sonjon Suchop(Reference book for teachers), 'A teacher's qualification is demonstrated by the student's competence in school subjects, and it determines the quality of education. ${ }^{, 17}$ For this, perhaps, the interviewees had good memories of their homeroom teachers and the reason was that they had fine characters. The respondents said that the North's personality education is one of the strong points of its education in which, they say, the state puts the greatest stress on humanity and manners. The country, by emphasizing ability as well as character for teachers and humanity as well as manners for students, gives priority to cultivating socialistic humanity required by its society rather than acquiring technical skills.

Considering the North's middle school curriculum and life, its in-class education aims for an ideological characteristic such as repeatedly telling Kim Il-sung's teachings - through this, the state is achieving part of its educational goal.

\section{THE GOAL OF KoREAN LANGUAGE EDUCATION IN MIDDLE SCHOOL}

North Korea's fundamental principle of guidance is to foster communistic people inheriting the spirit of anti-Japan armed struggle. Idolizing Kim Il-sung by inheriting the very spirit, the regime established a historical tradition that justifies its legitimacy. This tradition and the Juche ideology that is said to be advocated by Kim Il-sung, positioned him as a divine leader. In this context, it is justified for him to pass power to his son, Kim Jong-il and grandson, Kim Jong-un. The ultimate goal of the regime's education is to make all the students communistic revolutionary warriors who are loyal to Kim Il-

\footnotetext{
${ }^{17}$ Kyowon Sinmunsa(Teachers’ Newspaper). 'About “Let’s prime stu dents as trustworthy workers for the construction of Strong and Prosp erous Nation by raising the quality of education in keeping with the $n$ ew century!”', Kyowon Sonjon Suchop(Reference book for teachers) 3.Pyongyang: Kyowon Sinmunsa, 2005. p.33.
}

sung's family. To accomplish this goal, 'Kim Il-sung and Kim Jong-il's revolutionary ideology, the Juche ideology as well as the Juche language, and learning Kim Jong-il's theory' are suggested as the key educational goal. This goal is displayed well in the following quote.

Through our language, spoken and written, we will ensure that students will strengthen themselves with the great revolutionary ideology and the Juche ideology of our Great Leader Kim Il-sung, acquire a wealth of knowledge and ability for our language. ${ }^{18}$

According to Socialist Education(1988) published by Kim Hyong Jik University of Education, the content of socialist education is divided into four categories - political thoughts, science and technology, physical education, and emotional education. This is also seen in the system and the content of knowledge, of which Korean language education takes charge. The content regarding this in Methodology of Teaching Korean Language, issued in 1973, is presented as below.

First, it is to build up a linguistic ability, by improving general knowledge and skills of our spoken and written language to correctly grasp the party's policies, with which science, technology and socialistic culture can entirely be learnt. Second, it is to establish a foundation for fully participating in cultural life, which is one of the indispensable requisite for social life, and for creating professional literary art by acquiring general knowledge and basic ability about literary art. Third, it is to establish a foundation for autonomously and creatively organizing life and struggle, firmly based on the only ideology of the time, by enriching students' spiritual life, widening their practical knowledge and forming a basic ability to analyze reality. ${ }^{19}$

The text above reveals that Korean language education is to build up the basis for not only functional development of general knowledge but also correct comprehension of the party's policies. This is connected to the Juche ideology ${ }^{20}$ s principle of guidance. The first and the second sentences of the quotation above connote the purpose of fostering communistic human beings who can enjoy and develop socialistic culture by learning the language, and they are related to initiative and

${ }^{18}$ General Education Bureau of North Korea's Education Commissio $\mathrm{n}$, 'Outline of Teaching Korean Language and Literature(for fourth to sixth grades)', 1984. p.3.

${ }^{19}$ Educational Books Publisher. Methodology of Teaching Korean Language. Pyongyang: Kyoyuk Doso Chulpansa, 1973. pp.47-48.

${ }^{20}$ The Juche ideology had been North Korea's ideology, on which the Songun ideology is based, and the guide that ruled Joseon Rodongda ng and all the activities of the regime before the Songun ideology was introduced in 1996. In a set of ten volumes, the content of the Juche $i$ deology is divided into: (1)the Juche ideology, (2)the revolutionary the ory of Juche, (3)the Juche's guidance: (1) is subdivided into philosoph ical principle, socio-historical principle, and guiding rule. The philoso phical principle puts emphasis on anthropocentricity as well as guidin g rule emphasizes on initiative, awareness, and creativeness; (2)the re volutionary theory of Juche deals with the theory on revolutionary co nstruction and content of tactical strategies; (3) the Juche's guidance i s composed of reigning theory and communistic morality and life. 
awareness which are included in the principle. The third sentence relevant with emotional education, one can know that the ultimate goal is to foster new communistic human beings in that it is closely related to nurturing creative humans that the regime requires. The state's Korean language education, to fulfill this, stands on Kim Il-sung and Kim Jong-il's ideologies and theories on language and literature.

Until the early 1980s, Kim Il-sung's ideology on Korean language education was considered the sole and justifiable revolutionary theory that gave body to the Juche ideology. There are three reasons why: first, North Korea assumes that the national language education establishes the revolutionary outlook on the world of their next generations; second, the state supposes that the mission of the education is to foster developed new human beings; third, the state perceives the duty of the education as fostering newly-developed people.

These three requirements are relevant with the North's political ideology - the content of the political ideology education consists of the Juche ideology, policies of the party, tradition of revolution and communist revolution, which are the basis of ideology education. In other words, North Korea supposes that political-ideological education should be strengthened in order to raise talented revolutionary communists with the revolutionary outlook on the world, therefore, science and technology, physical education, and emotional education can successfully proceeded. Considering this, the state seems to judge that Korean language education can be huge part of educating students and changing them into newly-developed people.

\section{NORTH KOREA's CHANGE AND PROSPECT: IN PLACE OF A CONCLUSION}

As above, the reality of North Korea's education reality and its middle school education were looked into. The North's education at chalkface is little known. For the very reason, the author wrote this article utilizing reference materials and interviews with 38 North Korean defectors who have lived in the South for more than five years and currently are undergraduates or postgraduates in South Korea. This article firstly examined the general goals of North Korean education and the characteristics of the school curriculum. Next, this paper organized the features of the North's with the following points. First, a homeroom teacher is responsible for students from the first to the sixth grade. Second, students go to school earlier than the regular school hours in order to clean their surroundings and to be told Kim Il-sung's and Kim Jong-il's achievements or the current issue by their teachers. Third, students have free time after class, except when students who are 15 years old or older need to put efforts into both study and labor by being mobilized to supporting farming areas in farming seasons.

The ultimate objective, from another perspective, of North Korea's Korean language education is to foster newly developed communists. It is a principle that the texts included in North Korea's national language textbooks should stick to the communist partisanship and reflect socialistic patriotism. The present Korean language textbooks of the state have content mainly about the Juche Ideology, but the content was revised in 2002, adding content about the Songun ideology.
The textbooks for 4th and 5th grades, revised in 2004, have nothing different but Kim Jong-il's teaching on the first and the last pages.

After Kim Jong-il's death, although Kim Jong-un's succeeded his father, if he cannot take the power over the military in his hand as his father did, it seems that the Songun ideology will be reinforced and maintained as the regime's ideology. If so, this will constantly affect the content of North Korea's education. It is expected that the amount of Kim Ilsung and Kim Jong-il's literary works in the textbooks will be modified, and Kim Jong-un's teachings, ideology, and works will be added to textbooks that will be published in the state in the near future.

\section{REFERENCES}

[1] General Education Bureau of North Korea's Education Commission. People's School and Middle School curriculum outline. Pyongyang, 1984.

[2] Institute for Unification Education of Ministry of Unification. Understanding of North Korea 2006. Seoul: Ministry of Unification, 2006.

[3] Kim Il-sung. Kim Il-sung Chojakjip 32(1977.1 -1977.12). Pyongyang:Joseon Rodongdang Publisher, 1986.

[4] Kim Jong-il. Kim Jong-il Chojaksonjip 8. Pyongyang:Joseon Rodongdang Publisher, 2006.

[5] Kyowon Sinmunsa. Kyowon Sonjon Suchop 3. Pyongyang: Kyowon Sinmunsa, 2005.

[6] Ministry of Education. Unification Education Guide Materials. Seoul: Ministry of Education, 1993.

[7] Park Won Gyu. 'An Analysis on North Korea's Current Education Policy and Scientific Technology'. master's degree thesis at Graduate School of Kyunghee University, 1976.

[8] Seo Jae Cheon. 'A study of the transitional process of political education policies in the north Korean communist regime'. master's degree thesis at Graduate School of Seoul National University, 1981. 